Jurnal Penelitian Perawat Profesional

Volume 3 Nomor 1, Februari 2021

e-ISSN 2715-6885; p-ISSN 2714-9757

http://jurnal.globalhealthsciencegroup.com/index.php/JPPP

\title{
IDENTIFIKASI BAHAYA KESELAMATAN DAN KESEHATAN KERJA PADA AKTIVITAS NELAYAN
}

\author{
Dillyana Vinezzia \\ Fakultas Kedokteran, Universitas Lampung, Jl. Prof. DR. Ir. Sumatri Brojonegoro No.1, Gedong \\ Meneng, Kec. Rajabasa, Kota Bandar Lampung, Lampung, Indonesia 35145 \\ dillyana1006@gmail.com (+6282176873791)
}

\begin{abstract}
ABSTRAK
Indonesia merupakan negara kepulauan, dengan luas zona lautan lebih besar dari zona daratan. Salah satu mata pencaharian sektor bidang kelautan adalah nelayan. Dalam melakukan suatu pekerjaan, nelayan juga tak luput dari bahaya ataupun resiko kecelakaan di tempat kerja. Tujuan dari literature review ini adalah mengidentifikasi bahaya keselamatan dan kesehatan kerja pada aktivitas nelayan. Sumber pustaka yang digunakan berasal dari 11 artikel, 1 sumber kebijakan pemerintah, dan 6 buku-buku pedoman kesehatan, yang merupakan terbitan tahun 2003 hingga tahun 2019. Sumber pustaka tersebut selanjutnya dianalisis menggunakan metode Systematic Literature Review. Dari pemaparan didapatkan hasil bahwa saat nelayan melaut dapat timbul berbagai bahaya keselamatan dan kesehatan kerja baik saat di darat maupun saat di lautan. Bahaya yang ditimbulkan juga beragam, dari bahaya potensial kimia, bahaya potensial fisika, bahaya potensial ergonomi, bahaya potensial lingkungan, dan bahaya potensial psikososial.
\end{abstract}

Kata kunci: bahaya potensial; keselamatan dan kesehatan kerja; melaut; nelayan

\section{IDENTIFICATION OF OCCUPATIONAL SAFETY AND HEALTH HAZARD IN FISHING ACTIVITIES}

\begin{abstract}
Indonesia is an archipelago country, with an area of the ocean zone larger than the land zone. One of the livelihoods in the marine sector is fishermen. In doing a job, fishermen also do not escape the dangers or the risk of accidents at work. The purpose of this literature review is to identify occupational safety and health hazards in fishing activities. The library sources used came from 11 articles, 1 government policy source, and 6 health guidebooks, which were published from 2003 to 2019. The library sources were then analyzed using the Systematic Literature Review method. From the presentation, it was found that when fishermen go to sea, various occupational safety and health hazards can arise both on land and at sea. The hazards caused are also various, from chemical potential hazards, physical potential hazards, ergonomic potential hazards, environmental potential hazards, and psychosocial potential hazards.
\end{abstract}

Keywords: potential hazards; occupational safety and health; fishing; fishermen

\section{PENDAHULUAN}

Indonesia merupakan negara kepulauan terbesar se-Asia Tenggara. Dengan total wilayah Indonesia sebesar 7.810 .000 $\mathrm{Km}^{2}$, yang terdiri dari 2.010. $000 \mathrm{Km}^{2}$ merupakan zona daratan, dan 3.250.000 $\mathrm{Km}^{2}$ merupakan zona lautan. Indonesia memiliki sekitar 17.499 pulau yang tersebar dari Sabang hingga Marauke. Oleh karena itu dari zaman Kerajaan 
Sriwijaya, bahwa dijelaskan Indonesia merupakan negara maritim yang sebagian negara nya di kelilingi oleh lautan. Tidak heran bahwa pergerakan roda ekonomi Indonesia juga tidak hanya mengandalkan daratan, melainkan roda ekonomi lautan juga mengambil peran penting di Indonesia. Salah mata pencaharian sektor bidang kelautan adalah nelayan. Dalam Undang-undang Republik Indonesia No. 45 Tahun 2009, bahwa nelayan adalah orang yang mata pencahariannya melakukan penangkapan ikan. Nelayan bekerja secara musiman ataupun tidak, baik dipekerjakan di suatu kelompok tertentu atau perorangan. Pekerjaan nelayan adalah suatu pekerjaan tetap ataupun sambilan. Dengan waktu operasional yang ditentukan sendiri ataupun perkelompok (Pemerintah Indonesia, 2009).

Pekerjaan sebagai nelayan juga tak luput dari bahaya ataupun resiko kecelakaan di tempat kerja. Bahaya potensial memiliki arti sebagai sesuatu yang berpotensi untuk terjadinya insiden yang berakibat pada kerugian. Sedangkan risiko kecelakaan kerja adalah kombinasi dan konsekuensi suatu kejadian yang berbahaya dan peluang terjadinya kejadian tersebut (ILO, 2013). Tujuan dari artikel ini adalah mengidentifikasi bahaya keselamatan dan kesehatan kerja pada aktivitas nelayan dan jenis penelitian yang digunakan berbeda dengan penelitian lainnya, karena menggunakan metode Systematic Literature Review.

\section{METODE}

Penulisan ini menggunakan metode studi literature review. Sumber pustaka yang digunakan yaitu berasal dari kebijan pemerintah (undang-undang), penelitian-penelitian, buku-buku pedoman kesehatan yang diterbitkan pada tahun 2003 hingga tahun 2019. Sumber pustaka yang digunakan berasal dari 11 artikel, 1 sumber kebijakan pemerintah, dan 6 buku-buku pedoman kesehatan. Sumber pustaka tersebut dianalisis menggunakan metode Systematic Literature Review yaitu dengan melakukan pengumpulan, evaluasi, dan mengembangka penelitian pada topik tertentu.

\section{HASIL}

Nelayan hidup dalam suatu kondisi yang tidak menentu, dalam hal ini karakteristik yang dapat ditarik di kehidupan nelayan yaitu berakar dari kondisi lingkungan fisik dan sosial dimana seorang nelayang berkegiatan/bekerja. Laut merupakan tempat mata pencaharian nelayan. Laut merupakan lingkungan fisik dimana biota laut dan sebagainya itu hidup. Dalam hal ini, biota laut mengalami perpindahan/migrasi, baik bergantung musim ataupun tidak, yang menyebabkan sulitnya penangkapan biota laut itu sendiri. (Acheson dalam Wahyono, 2016). Selain kondisi biota laut yang mengalami perpindahan, kegiatan mengarung lautan juga berdasarkan kondisi cuaca saat itu. Cuaca adalah suatu fenomena atau perubahan yang terjadi di wilayah tertentu yang menunjukkan adanya perubahan aktifitas alam seperti hujan, panas matahari, atau mendung (Saefudin dalam Khalfianur, Niati, \& Harahap, 2017).

Terlepas dari faktor-faktor yang harus diperhatikan saat melaut, peralatan yang digunakan untuk melaut juga menentukan hasil yang akan didapatkan. Karena alat penangkapan ikan berkembang cukup variatif, dari yang berukuran kecil (tombak, serok dan pancing) sampai dengan yang berukungan besar (rawl, purse seine, 
rawai tuna serta payang), semua bergantung pada kearifan lokal di daerahnya masing-masing (Purwangka et al., 2013). Setiap alat dapat menentukan jumlah tangkapan yang akan diperoleh terlepas dari jam kerja yang juga menentukan. Selain itu juga, nelayan dapat melakukan penyelaman untuk menggiring biota laut masuk ke perangkap ataupun melakukan pengecekan peralatan penangkap ikan (jaring) yang sudah dipasang. Penyelaman tersebut dilakukan dengan cara tradisional, hanya mengandalkan kompresor yang digunakan sebagai penyedia udara saat nelayan berada di dalam air (Dharmawirawan \& Modjo, 2012).

Rangkaian kegiatan melaut terdiri dari sembilan tahap, yaitu persiapan di darat, pemindahan (loading) ke atas perahu, berlayar menuju daerah penangkapan ikan, persiapan alat tangkap, pengoperasian alat tangkap, pengangkatan alat tangkap (hauling), penanganan hasil tangkapan, berlayar menuju pelabuhan asal (fishing base), dan unloading hasil tangkapan dan alat tangkap (Purwangka et al., 2013). Dalam rangkaian kegiatan, pastilah terdapat suatu bahaya potensial yang ada di lingkungan kerja tersebut, maupun resiko dari pekerjaan yang dapat menimbulkan kecelakanaan kerja. Bahaya potensial yang timbul dalam kegiatan melaut berupa bahaya potensial kimia, fisika, biologi, ergonomi, lingkungan, dan psikososial.

\section{PEMBAHASAN}

Bahaya potensial kimia yang menghantui nelayan dapat terjadi pada aktifitas hauling atau pengangkatan alat tangkap, terdapat satu aktifitas yang mengakibatkan pajanan berulang, yaitu saat juru mudi mulai memainkan rpm perahu. Bahaya dalam hal ini yaitu bahaya kimia berupa asap buangan dari mesin perahu. Selain asap, terdapat juga bahaya kimia lain yang ada disekitar nelayan, yaitu ketika melakukan aktifitas penyelaman menggunakan kompresor. Kompresor digunakan sebegai penyedia udara saat dibawah air. Kompresor dimodifikasi dengan menggunakan selang panjang tanpa ada filter. Saluran masuk yang berdektan dengan knalpot kompresor, membuat kualitas udara yang dihasilkan cukup buruk (Dharmawirawan \& Modjo, 2012).

Asap dari mesin perahu dan udara pada kompresor, sama-sama menghasilkan emisi $\mathrm{CO}$ dan $\mathrm{CO}^{2}$. Yang mana emisi $\mathrm{CO}$ tersebut dapat berikatan dengan hemoglobin/Hb dan membentuk karboksihemoglobin (COHb) dalam darah, yang nantinya akan mempengaruhi kadar oksigen dalam darah (Ismiati, Marlita, \& Saidah, 2014). Sedangkan untuk emisi $\mathrm{CO}^{2}$ yang nilainya melebihi ambang maka akan menyebabkan keracunan (Dharmawirawan \& Modjo, 2012). Apabila mesin perahu menggunakan bahan bakar berupa bensin ataupun solar, maka asap yang dikeluarkan memiliki beberapa senyawa tambahan di samping senyawa tersebut di atas, yang terutama adalah fraksi-fraksi organik seperti aldehida, PAH (Poli Alifatik Hidrokarbon), yang mempunyai dampak kesehatan yang lebih besar (karsinogenik), dibanding dengan senyawa-senyawa lainnya (Ismiati, Marlita, \& Saidah, 2014). Bahaya asap juga dapat menimbulkan berbagai resiko penyakit yang berkaitan dengan saluran pernapasan. Didukung oleh data pada Pusat Data dan Informasi Kementrian Kesehatan RI, bahwa angka ISPA (Infeksi Saluran Pernapasan) pada nelayan memiliki nilai proporsi nomor 
dua tertinggi yaitu 12,8 (Kemenkes RI, 2015).

Bahaya potensial fisika yang timbul dalam kegiatan melaut salah satunya adalah kebisingan. Kebisingan disini dihasilkan oleh dua mesin, yaitu mesin perahu yang selalu hidup, dan mesin kompresor yang hanya hidup saat pada tahapan persiapan, pengoprasian, dan pengangkatan alat tangkap. Menurut ILO (2013) bahwa batasan pajanan ambang kebisingan pada pekerja hanyalah $85 \mathrm{~dB}$ selama 8 jam perhari. Menurut jurnal yang ditulis oleh Usior, Pangalila, \& Kaparang (2014) pada penelitian yang di lakukan pada kapal dengan mesin tempel bahwa tingkat kebisingan yang tertinggi pada saat menuju ke fishing ground/DPI berada sebesar 97,8 dB dan nilai terendah sebesar 48,7 dB. Tingkat kebisingan yang tertingggi pada saat alat tangkap dilepas sebesar 89,9 dB dan terendah sebesar 30,0 dB. Tingkat kebisingan yang tertinggi pada kondisi alat tangkap ditarik (hauling) sebesar 77,64 dB dan terendah sebesar 31,7 dB. Tingkat kebisingan yang tertinggi pada saat kembali ke fishing base sebesar 99,7 $\mathrm{dB}$, dan terendah sebesar 51,7 dB.

Mesin kapal biasanya dihidupkan dalam kurun waktu \pm 10 jam (mengikuti jam kerja nelayan). Sedangkan mesin kompresor biasanya dihidupan dalam kurun waktu $<8$ jam (Dharmawirawan \& Modjo, 2012). Karena paparan yang terus menerus, hal ini dapat menyebabkan penurunan fungsi pendengeran. Derajat gangguan pendengaran berdasarkan International Standard Organization (ISO) adalah normal $(0-25 \mathrm{~dB})$, tuli ringan $(26-40$ $\mathrm{dB})$, tuli sedang $(41-60 \mathrm{~dB})$, tuli berat $(61-90 \mathrm{~dB})$, dan tuli sangat berat $(>90$ dB).
Bahaya fisika lainnya adalah paparan cahaya matahari yang dapat menyebabkan sunburn. Paparan cahaya matahari UV A muncul di bawah jam 10 pagi. Sedangkan UV B muncul di atas jam 10 pagi. Paparan UV A dapat menembus hingga dermis yang menyebabkan penuaan, sedangkan paparan UV B dapat menembus hingga epidermis yang menyebabkan sensasi kulit terbakar (Isfardiana \& Safitri, 2014). The National Institute for Health and Care Excellent (2016), memaparkan bahwa pada pukul 10 pagi hingga 3 siang, adalah saat pancaran solar UV tertinggi, satu sisi kondisi ini baik untuk membantu penyerapan vitamin $\mathrm{D}$, tetapi kondisi lain dapat menimbulkan banyak dampak yaitu berupa kemerahan pada kulit, sunburn, dan menimbulkan eritema yang diakibatkan oleh sinar UV B. Dampak lainnya adalah pemicu timbul katarak, menimbulkan resiko kanker, dan mengurangi elastisitas kulit (Isfardiyana \& Safitri, 2014).

Selain resiko suhu panas, resiko suhu dingin juga dapat mempengaruhi kesehatan nelayan yang melakukan aktifitas menyelam dan mengangkat bongkahan es. Penyelam hanya menggunakan baju alakadarnya dan tidak menggunakan baju sesuai standar penyelaman, yang ditakutkan akan menimbulkan kondisi hipotermi di bawah air. Menyelam begitu lama, dapat membuat kalor dalam tubuh kita lepas. Dan tubuh akan mengalami penurunan suhu, yang dapat menimbulkan hipotermia. Hipotermia terjadi karena lepasnya panas karena konduksi, konveksi, radiasi, dan evaporasi, sehingga suhu tubuh dapat mencapai $<35^{\circ} \mathrm{C}$. (Dharmawirawan \& Modjo, 2012). 
Bahaya potensial biologi yang mengintai para nelayan, biasanya adalah bahaya yang ditimbulkan dari hewan atau biota laut. Bahaya biologi sendiri dapat sangat dirasakan pada nelayan yang melakukan penyelaman dan bertugas menggiring ikan. Beberapa biota laut yang cukup berbahaya yang ada di lautann adalah ikan hiu, ikan barakuda, moray eal, ubur-ubur, bulu babi, ular laut, dan anemon laut. Seperti ikan hiu, yang cukup sensitif terhadap bau darah, ikan barakuda yang akan menyerang seseorang yang mengenakan benda logam, dan moray eal yang sering menyerang apabila nelayan melewati lubang tempat tinggalnya (Dharmawirawan \& Modjo, 2012). Bahaya lainnya adalah sengatan uburubur. Gejala yang biasa timbul akibat sengatan ubur-ubur adalah gatal-gatal dan demam. Apabila warna ubur-ubur semakin mencolok makan tingkat racun yang dimiliki cukup berbahaya bahkan bisa sampai menyerang jantung dan mematikan korban yang tersengat (Muntasib et al., 2018).

Bahaya racun lainnya ada pada bulu babi, ular laut, dan anemon laut. Ular laut yang berwarna dominan kuning dan bercak hitam dengan panjang sekitar 60 $\mathrm{cm}$ yang biasa ditemukan bersembunyi pada terumbu karang, saat air laut dalam keadaan surut maka akan di temukan sekitar pasir. Ular laut sendiri merupkan hewan berbisa, dengan daya racun atau virulensi yang relatif lebih kuat dibandingkan ular yang hidup di darat. Komposisi kimia bisa ular pada umumnya merupakan suatu kompleks protein yang bersifat netral atau sedikit asam dan bersifat toksin yang disebut erabu toksin. Bisa/toksin ular laut yang masuk tubuh akan bergabung dengan darah, dan menyerang fungsi otak dengan menghambat kerja saluran pernapasan dan merusak eritrosit.
Sebagaimana diketahui, bahwa korban yang terkena gigitan ular laut akan pusing dan mengalami kejang, kehilangan kesadaran, dan bahkan kematian dalam beberapa jam atau hari (Muntasib et al., 2018).

Dan kasus tersering yang dialami nelayan adalah sengatan bulu babi. Bulu babi merupakan kelompok hewan dengan permukaan berduri yang masuk dalam filum Ekhinodermata (Pratiwi, 2006). Nelayan yang bertugas sebagai penyelam lah yang biasa terkena tusukan bulu babi, dikarenakan tidak menggunakan alas kaki dan mudah sekali tertusuk durinya sehingga akan sedikit merasakan demam karena bisa/toxin pada duri tersebut, racunnya sendiri dapat dinetralisir dengan amoniak, atau perlakuan asam ringan (jeruk lemon atau cuka) (Muntasib et al., 2018). Bahaya sengatan lainnya adalah anemon laut. Sebenarnya anemon laut merupakan kelompok Pomacentridae, yang masuk dalam kategori ikan hias. Anemon laut biasa melakukan simbiosis dengan biota laut lain, yang mana tubuh anemon laut digunakan sebagai tempat berlindung bagi ikan, udang, dll. Tetapi sama halnya dengan hewan lainnya, anemon laut memiliki sistem pertahanan berupa sengatan (Pratiwi, 2006).

Selain itu juga terdapat bahaya stuck agains yaitu tergoresnya kulit akibat terumbu karang (Dharmawirawan \& Modjo, 2012). Terumbu karang sendiri merupakan hewan yang biasa disangka sebagai tumbuhan, bagian keras pada karang adalah cangkang dari hewan karang batu, yang tersusun dari zat kapur $\mathrm{CaCO} 3$. Bagian lunak disebut polip karang dan berbentuk seperti tabung disertai tentakel yang berjumlah 6 buah atau kelipatannya serta terletak di keliling mulut (Pratiwi, 2006). 
Selain bahaya yang ada di dalam air, perlu ketahui bahwa terdapat bahaya yang cukup lumrah dikalangan penduduk pesisir, yaitu bahaya gigitan nyamuk. Yang mana kasus terbanyak adalah malaria. Nilai proporsi penyakit pada nelayan yang ditampilkan pada Pusat Data dan Informasi Kemenkes RI, bahwa malaria memiliki nilai sebesar 3,2 (Kemenkes RI, 2015). Malaria sendiri adalah penyakit infeksi parasit yang disebabkan oleh plasmodium yang menyerang eritrosit dan ditandai dengan ditemukannya bentuk aseksual di dalam darah. Dan pembiakan seksual sendiri terjadi di nyamuk anopheles betina. Berdasarkan tempat perindukannya, vektor malaria dapat dikelompokkan dalam tiga tipe yaitu berkembang biak di daerah persawahan, perbukitan/hutan dan pantai/aliran sungai. Infeksi malaria sendiri akan menyebabkan demam, menggigil, anemia bahkan sphlenomegali (Harijanto, 2009).

Bahaya potensial ergonomi terjadi karena hubungan pekerjaan dan tubuh manusia. Potensi bahaya ergonomi akan meningkat apabila tugas yang dilakukan monoton, berulang atau kecepatan tinggi, dengan postur yang tidak netral, pendukung yang kurang sesuai, dan waktu istirahat yang tidak cukup (ILO, 2013). Bahaya ergonomi dapat ditemukan saat pengecekan kondisi selang, mengeluarkan kerincingan, menghidupkan mesin kompressor, dan menurunkan atau menaikan jaring. Saat melakukan pengecekan selang selama kurang lebih 20-30 menit, nelayan bertumpu pada dua kaki dan dengan posisi membungkuk dengan waktu yang cukup lama, yang menyebabkan penegangan otot ekstremitas bawah dan tulang punggung. Selain itu juga aktifitas mengeluarkan kerincingan juga memiliki potensi bahaya ergonomi, dikarenakan saat melakukan pekerjaan ini posisi kaki telalu menekuk (jongkok) dalam waktu yang lama, yang menyebabkan sensasi kesemutan dan kelelahan pada ekstremitas bagian bawah. Sedangkan aktifitas menaikan dan menurunkan jaring juga dapat mengakibatkan kelelahan otot, dikarenakan posisi dan kegiatan repitisi saat melakukan ini. Nelayan akan sedikit membungkuk, dan menahan/menarik beban yang cukup berat dengan frekuensi kegiatan sebanyak 8 kali dalam durasi waktu kurang lebih 10 menit per hauling (Dharmawirawan \& Modjo, 2012).

Bahaya potensial ergonomi pada nelayan, kebanyakan adalah gerakan repetisi. Kegiatan berulang-ulang dan dalam jangka waktu cukup lama yang menggunakan ekstremitas atas, leher, dan punggung dapat menimbulkan Cumulative Trauma Disordes (CTD). CTD terjadi karena penggunaan otot yang harus selalu berada dalam keadaan kontraksi baik melakukan kegiatan berulang atau menopang sesuatu. Kegiatan yang tidak ergonomis tersebut akan menimbulkan kelelahan otot bahkan robekan mikroskopis yang selanjutnya diikuti oedema, inflamasi, dan gangguan fungsi (Albar, 2009).

Gerakan membungkuk begitu lama, dapat membuat kemungkinan penyakit LBP/Low Back Pain. LBP atau nyeri (nyeri lokal atau nyeri radikuler) atau tidak nyaman pada bagian punggung. Faktor risiko terjadinya LBP dari pekerjaan meliputi postur punggung yang membengkok atau berputar yang sering dan berkelanjutan, postur statis, pekerjaan tak beraturan, pengangkatan barang, gerakan punggung yang berputar cepat yang berlebihan, dorongan dan penarikan, intensitas kerja tinggi, kerja berulang, paparan getaran seluruh tubuh atau Whole Body 
Vibration (WBV), dan kehilangan keseimbangan saat punggung membawa beban (Ehlich, 2003).

Bahaya potensial lingkungan merupakan suatu bahaya yang cukup kompleks. Karena selain melihat dari sisi alam, juga melihat dari sisi area kapal. Seperti halnya lantai licin di area kapan, dapat membuat nelayan terpeleset dan menimbulkan cidera. Kondisi kapal yang selalu basah terkena ombak, membuat lantai kapal akan lembab dan licin. Selain itu juga terdapat kondisi ombak dan cuaca yang tidak menentu dapat menyebabkan kapal oleng bahkan tenggelam. Kondisi jarak pandang saat menyelam pun akan terganggu apabila kondisi cuaca sedang buruk. Pada kondisi ini penyelam akan kehilangan orientasi dan sulit memprediksi arus, yang tak jarang penyelam akan terbelit terbawa arus atau terbeli perangkap sendiri (Dharmawirawan \& Modjo, 2012).

Bahaya potensial psikososial dapat timbul dari berbagai macam aspek, yaitu kondisi alam yang tidak menentu, tingkat pendidikan nelayan yang rendah, pola kehidupan nelayan yang konsumtif, kurang maksimalnya pemasaran hasil tangkapan, dan program pemerintah yang belum memihak nelayan. Dari aspek-aspek inilah akan menimbulkan stresor tersendiri di kehidupan nelayan, yang akan menimbulkan hambatan saat bekerja dan penurunan produktivitas (Manurung, Sutanti, \& Adam, 2017).

Gangguan psikososial yang timbul pada nelayan adalah sebuah rasa khawatir atau gangguan cemas. Gangguan cemas sendiri terjadi akibat interaksi faktor biopsikososial, termasuk kerenatanan genetik yang berinteraksi dengan kondisi tertentu, stres atau trauma yang menimbulkan sindrom klinis yang bermakna (Redayani, 2015). Gangguan cemas yang terjadi pada nelayan dapat timbul karena beberapa aspek, yaitu kondisi alam yang tidak menentu, tingkat pendidikan nelayan yang rendah, pola kehidupan nelayan yang konsumtif, kurang maksimalnya pemasaran hasil tangkapan, dan program pemerintah yang belum memihak nelayan (Manurung, Sutanti, \& Adam, 2017). Yang nantinya akan menimbulkan sebuah kecemasan atau ketakutan tersendiri, yang akan menurunkan produktivitas dari nelayan.

\section{SIMPULAN}

Nelayan adalah suatu mata pencaharian sektor bidang kelautan, yang bekerja secara musiman ataupun tidak, baik dipekerjakan di suatu kelompok tertentu atau perorangan. Pekerjaan nelayan adalah suatu pekerjaan tetap ataupun sambilan, dan dengan waktu operasional yang ditentukan sendiri ataupun perkelompok. Rangkaian kegiatan melaut terdiri dari sembilan tahap, yaitu persiapan di darat, pemindahan (loading) ke atas perahu, berlayar menuju daerah penangkapan ikan, persiapan alat tangkap, pengoperasian alat tangkap, pengangkatan alat tangkap (hauling), penanganan hasil tangkapan, berlayar menuju pelabuhan asal (fishing base), dan unloading hasil tangkapan dan alat tangkap. Dalam rangkaian kegiatan melaut tersebut dapat muncul berbagai bahaya keselamatan dan kesehatan kerja pada nelayan. Bahaya potensial tersebut dapat timbul dari berbagai aspek, seperti bahaya kimia, fisika, biologi, ergonomi, lingkungan, dan psikososial. Bahaya potensial tersebut di khawatirkan dapat menjadi sumber dari kecelakaan kerja atau penyakit akibat kerja. 
DAFTAR PUSTAKA

Albar. (2009).

Gangguan Muskuloskeletal Akibat Kerja dalam Ilmu Penyakit Dalam UI Jilid 2. Jakarta: Interna Publishing.

Dharmawirawan, D. A., \& Modjo, R. (2012). Identifikasi Bahaya Keselamatan dan Kesehatan Kerja pada Penangkapan Ikan Nelayan Muroami. Jurnal Kesehatan Masyarat Nasional, 6 (4), 185192, http://jounal.fkm.ui.ac.id/

Ehlich. (2003). Low Back Pain. Bulletin of the World Health Organization, 81(9), 671-676, http://www.who.int/

Harijanto. (2009). Malaria dalam Buku Ilmu Penyakit Dalam Jilid 3. Jakarta: Interna Publishing.

ILO. (2013). Keselamatan dan Kesehatan Kerja. Jakarta: International Labour Organization.

Isfardiyana, S. H., \& Safitri, S. R. (2014). Pentingnya Melindungi Kulit dari Sinar Ultra Violet dan Cara Melindungi Kulit dengan Sunblock Buatan Sendiri. Jurnal Inovasi dan Kewirausahaan, 3(2), 126-133, http://journal.uii.ac.id/

Ismiati, Marlita, D., \& Saidah, D. (2014). Pencemaran Udara Akibat Emisi Gas Buang Kendaraan Bermotor. Jurnal Manajemen Transportasi \& Logistik, 1(3), 241-247, http://journal.itltrisakti.ac.id/

Kemenkes RI. (2015). Pusat Data dan Informasi Kemenkes RI (Situasi Kesehatan Kerja). Jakarta: Kementrian Kesehatan Republik Indonesia.
Khalfianur, W., Niati, C. R., \& Harahap, A.. (2017). Pengaruh Gelombang Laut Terhadap Hasil Tangkapan Nelayan Di Kuala Langsa. Jurnal Samudra Akuatika, 1(2), 21-25, http://jurnal.unsam.ac.id/

Manurung, A. D. R., Sutanti, Y. S., \& Adam, D. (2017). Analisis Stres Kerja dan Upaya Intervensi Psikologi Kerekayasaan dalam Mengatasi Stres Kerja Nelayan Tradisional Tanjung Peni Citangkil dan Nelayan Grogol Pesisir Pantai Cilegon, 2(1), 3545, http://www.s2tmi.itb.ac.id/

Muntasib, EKS, H., Ulfah, M. M., Samosir, A., Meilani, R. (2018). Potensi Bahaya Bagi Keselamatan Pengjunung di Kawasan Wisata Pantai Pangandaran Kabupaten Pangandaran Jawa Barat. Jurnal Pengelolaan Sumberdaya Alam dan Lingkungan, 8(1), 15-25, http://journal.ipb.ac.id/

Pratiwi, R. (2006). Biota Laut : I. Bagaimana Mengenal Biota Laut. Jurnal Oseana LIPI, 31 (1), 27 38 ,

http://www.oseanografi.lipi.go.id/

Purwangka, F., Wisudo, S. H., Iskandar, B. H., \& Haluan, J. (2013). Identifikasi Potensi Bahaya dan Teknologi Keselamatan Kerja pada Operasi Perikanan Payang di Palabuhanratu, Jawa Barat. Jurnal Kelautan Nasional, 8 (2), 60-72, http://ejournalbalitbang.kkp.go.id/

Redayani. (2015). Buku Ajar Psikiatri Edisi Ketiga. Jakarta: Badan Penerbit FK UI.

The National Institute for Health and Care Excellent. (2016). Sunlight 
Exposure: Risk and Benefit.

United Kingdom, nice.org.uk/guidace/ng34.

Pemerintah Indonesia. (2009). Undangundang Republik Indonesia No. 45 Tahun 2009 Tentang Perikanan. Jakarta: Sekertaris Negara.

Usior, O. T., Pangalila, F. P. T., \& Kaparang, F. E. (2014). Pengukuran tingkat kebisingan pada kapal pukat cincin KM. Sumber Jaya bermesin tempel di perairan Teluk Manado. Jurnal Ilmu dan Teknologi Perikanan Tangkap 1(Edisi Khusus), 92-98, http://ejournal.unsrat.ac.id

Wahyono, A. (2016). Ketahanan Sosial Nelayan: Upaya Merumuskan Indikator Kerentanan (Vulnerability) Terkait dengan Bencana Perubahan Iklim. Jurnal Masyarakat Indonesia, 42(2), 185-199, http://jmi.ipsk.lipi.go.id/ 
Jurnal Penelitian Perawat Profesional, Volume 3 No 1 Hal 117 - 126, Februari 2021 Global Health Science Group 